\title{
Selected Reference Books of 1981-82
}

$\mathrm{T}$ HIS ARTICLE continues the semiannual series originally edited by Constance $\mathrm{M}$. Winchell. Although it appears under a by-line, the list is a project of the Reference Department of the Columbia University Libraries, and notes are signed with the initials of the individual staff members. ${ }^{1}$

Since the purpose of the list is to present a selection of recent scholarly and general works of interest to reference workers in university libraries, it does not pretend to be either well balanced or comprehensive. A brief roundup of new editions of standard works, continuations, and supplements is presented at the end of the article. Code numbers (such as $\mathrm{AJ} 41$, BE69, 2CD13) have been used to refer to titles in the Guide to Reference Books and its supplements. ${ }^{2}$

\section{BIBLIOGRAPHY}

Winans, Robert B. A Descriptive Checklist of Book Catalogues Separately Printed in America, 1693-1800. Worcester, Mass., American Antiquarian Society, 1981. 207p. \$35. LC 80-69713. ISBN 0-91229647-X.

Separately published book catalogs "issued in America prior to 1801 by booksellers, publishers, book auctioneers, circulating libraries, social libraries, college libraries, and private libraries" (Introd.) are listed and described in this checklist. Within a chronological arrangement, items that have been located (i.e., entries for 278 located items plus 8 others not known to be extant, but for which there is good evidence of publication) are numbered, whereas unlocated items

1. Rita Keckeissen, Anita Lowry, Eileen McIlvaine, Mary Ann Miller; Lehman Library: Laura Binkowski, Diane Goon.

2. Eugene P. Sheehy, Guide to Reference Books (9th ed.; Chicago: American Library Assn., 1976); Supplement (Chicago: American Library Assn., 1980); 2d Supplement (Chicago: American Library Assn., 1982). (some 393 entries "assigned a lesser status because many if not most of them may be bibliographic ghosts") are unnumbered and, in lieu of location symbols, reference is made to earlier bibliographies or other sources from which the citation derives. There is an index of authors (including libraries as corporate authors, booksellers, auctioneers, etc.), printers, subjects, and places of publication.

The checklist forms the first published results of a project designed to provide similar coverage for all American eighteenthcentury book catalogs; further segments will list catalogs published as part of a larger unit and catalogs in manuscript. - E.S.

\section{MANUSCRIPTS}

Braswell, Laurel Nichols. Western Manuscripts from Classical Antiquity to the Renaissance: A Handbook. New York, Garland, 1981. 382p. (Garland Reference Library of the Humanities, V.139) \$50. LC 79-7908. ISBN 0-8230-9541-3.

Addressed to the student of paleography, this pioneering manual is designed to bring together bibliographies from many disciplines "to facilitate the study of Western manuscripts" (Introd.) from classical antiquity to the early Renaissance. Emphasis is on sources important for British manuscripts inasmuch as the work will be used chiefly in the English-speaking world.

Materials are presented in fifteen sections, each with appropriate subdivisions, conceived as successive stages in identification, transcription, and interpretation of a manuscript, its cultural context, and ultimately, its edition. Subsections for individual specialties (e.g., writing and script, diplomatics, codicology, illumination, textual criticism), however, have their own interest and can be used profitably by the student of calligraphy, of medieval studies, of the history of the book, etc., a circumstance that bears out the compiler's conviction of the interdisciplinary 
character of paleography. Both books and articles are listed, with each entry carrying full bibliographical details as well as a brief descriptive or evaluative annotation. There is a high percentage of English-language works, but important writings in foreign languages are also included. The index is chiefly of authors and editors; for a subject approach, the reader must depend on the detailed table of contents prefixed to each section. - R.K.

\section{Libraky Resources}

Grant, Steven A., and Brown, John H. The Russian Empire and Soviet Union: A Guide to Manuscripts and Archival Materials in the United States. Boston, G. K. Hall, 1981. 632p. \$75. LC 81-6306. ISBN 0-8161-1300-9.

University and research libraries and archives, museums, business, ethnic and other organizations, federal and state archives, historical societies, and owners of private collections in the continental United States, $\mathrm{Ha}$ waii, and Alaska are all included in this catalog of manuscript holdings "that relate to the Russian Empire, Soviet Union, and the many distinct nationalities therein."Introd. Wide as the net is, there is no claim that the result is an exhaustive listing; only highlights will have been mentioned for some collections; others may have been inadequately described. Nevertheless, this ambitious work, covering materials in many forms - correspondence, organizational records, diaries, memoirs, literary manuscripts, photographs, films, tape recordings, and graphic materials - which bear on political, historical, social, economic, diplomatic, artistic, religious, and military matters, will be a welcome addition at any institution in which advanced work in Slavic studies is important.

Descriptions (collected by personal visits, by correspondence, and from published finding aids) are arranged alphabetically by state, then city, then repository. Entries include names and dates of persons or organizations; subject; general description of the collection; details of the Russian-related items; conditions affecting access; and citations to finding aids. There is a full index of names and subjects. $-R . K$.

\section{Government Publications}

Coxon, Howard. Australian Official Publications. Oxford, Pergamon Pr., [1980]. 122p. il. (Guides to Official Publications, V.5) \$36. LC $80-40046$. ISBN $0-08$ 023131-4.

Richard, Stephen. Directory of British Official Publications: A Guide to Sources. [London], Mansell (dist. in U.S. by H. W. Wilson), [1981]. 360p. \$58. ISBN 0-72011596-5.

Westfall, Gloria. French Official Publications. Oxford, Pergamon Pr., [1980]. 209p. il. (Guides to Official Publications, V.6) \$35. LC 80-40418. ISBN 0-08021838-5.

Several volumes of Pergamon's “Guides to Official Publications" series offer surveys of governmental publishing in individual countries presented with some degree of conformity but without strict adherence to a pattern: the Coxon and Westfall volumes are representative additions to the series. Both provide information on the types of official publications and their dissemination, the historical background, problems of acquisition, and citations to bibliographies and indexes. As an English-language guide to French government documents and related publications, the Westfall work is particularly welcome - not least because of its separate chapter on the Journal Officiel.

In many respects, Coxon's volume compares favorably with the volume of the same title edited by D. H. Borchardt (Melbourne, Longman Cheshire, 1979; Suppl. 2AG14), although the latter may be preferred for its somewhat more discursive essay style and more extensive bibliographies.

As the title clearly indicates, Richard's work is a directory to the sources of British official publications - the organizations which issue and distribute them - not a bibliography of the publications themselves. Organizations are grouped geographically (i.e., United Kingdom, Great Britain, England and Wales; Northern Ireland; Scotland, etc.), then by type (central government; libraries, museums, galleries; research council establishments, etc.). Entries provide information on the types of publications issued, the subjects covered, availability of the publications, and addresses to which orders or 
requests for further information should be directed. - E.S.

\section{BIOGRAPHY}

Bartke, Wolfgang. Who's Who in the People's Republic of China. Armonk, N.Y., M. E. Sharpe; Brighton, Eng., Harvester Pr., [1981]. 729p. il. \$100. LC 80-27599. ISBN 0-87332-183-9.

"A publication of the Institute of Asian Affairs in Hamburg." - t.p.

Intended as a guide to the currently active leaders of the People's Republic of China, this new biographical dictionary focuses on government, party, and mass organization officials. The work is based on files maintained by the compiler from 1958, with information drawn "primarily from the daily Chinese press . . . and reports from the Summary of World Broadcasts of the BBC."Pref. Details concerning date and place of birth, education, etc., were often not available, and numerous entries consist only of indication of positions held and a chronology of appointments and official activities. Many entries include a photograph of the biographee. Names are entered according to the pinyin system of transliteration; Chinese characters and Wade-Giles romanization of the names are also given. An extensive appendix offers background tables and various lists of party, government, and mass organization officials. - E.S.

\section{Biographical Dictionary of American May-} ors, 1820-1980: Big City Mayors. Ed. by Melvin G. Holli and Peter d'A. Jones. Westport, Conn., Greenwood Pr., 1981. 45lp. \$69.50. LC 80-1797. ISBN 0-31321134-5.

The big cities whose mayors are documented in this volume are: Baltimore, Boston, Buffalo, Chicago, Cincinnati, Cleveland, Detroit, Los Angeles, Milwaukee, New Orleans, New York, Philadelphia, Pittsburgh, San Francisco, and St. Louis. Though recent years have seen certain shifts in the centers of population and influence toward newer, sunnier cities, these fifteen great urban centers of the East, Midwest, and coastal waters are those that have "maintained consistent leadership in population and historical importance since the 1820s."-p.xii.
(Washington, D.C., was excluded as a rather special case, but is to be included in a future volume.)

The editors (codirectors of the Project for the Study of American Mayors) and the 100 other contributors have drawn largely on archival and primary resource research in writing about each of the 679 mayors. Basic biographical information, electoral statistics, brief political analysis, and bibliographic sources are provided for every mayor, living or dead, from the most famous to the most obscure (many of the latter would not easily be found in other sources). There are five appendixes listing the mayors by city, political party, ethnic background, religious affiliation, and place of birth; seven additional appendixes provide historical demographic statistics (up through the 1970 census) for the fifteen cities. An index of names and subjects completes the volume. $-A$. $L$.

\section{LITERATURE}

Foster, David William. Mexican Literature: A Bibliography of Secondary Sources. Metuchen, N.J., Scarecrow Pr., 1981. 386p. \$22.50. LC 81-8871. ISBN 0-8108-1499-8.

Foster points out that the three "touchstones" of Spanish American literatureArgentina, Mexico, and Peru-have long been lacking bibliographies of representative criticism of their major authors (time and burgeoning scholarly activity having left his 1970 Research Guide to Argentine Literature incomplete and out of date). This work is an attempt to remedy that situation for Mexican literature.

Fifty authors since the colonial period were chosen on the "basis of their historical and aesthetic importance and on the basis of available critical references."-Pref. These references include criticism and review articles in scholarly and cultural journals, articles reprinted in collective works, monographs, doctoral dissertations, and bibliographies. Reviews are cited only if an author has not accumulated a large body of criticism. Preceding the sections for individual authors are seventy-six pages of general references arranged hierarchically (beginning with bibliographies, general histories, collected essays, etc.), then by period, genre, and region. Mexico's indigenous literature is 
excluded; the cutoff date is $1978 / 79$.

The bibliography's extensiveness is testimony to the industry of the compiler, who was handicapped by lack of consecutive, cumulative Latin American periodical indexes for much of the period of coverage. We are much in his debt. - M.A.M.

Hager, Philip E. and Taylor, Desmond. The Novels of World War I: An Annotated Bibliography. New York, Garland, 1981. 513p. (Garland Reference Library of the Humanities, V.232) \$40. LC 80-8496. ISBN 0-8240-9491-3.

Hager's 800-entry checklist (published in Bulletin of Bibliography, Oct.-Dec. 1977) has here been expanded to include some 900 adult and 370 juvenile novels which "use World War I conflict either as a substantial part of the action or whose plot is set wholly or in part against the 1914-1918 war period."-Pref. Policies of inclusion and exclusion are set forth in some detail: e.g., included are short novels if bound separately; excluded are war memoirs; included are English translations; excluded are novels "that show the effect of the war on postwar life and activities."

Earliest publication date and complete bibliographical details are given for each novel cited. If a copy of the novel could not be located, the source of the citation is given. Annotations are carefully prepared, for in a few sentences the work is described in sufficient detail to indicate the story line and its relation to the war, its value, and the intended audience. Arrangement is chronological within the separate adult and juvenile sections.

Of special interest are the essays (giving a brief survey of the various themes in the novels) that precede each section, and the extensive bibliography of critical materials books, dissertations, essays, and periodical articles. There are author and title indexes, but some topical indexing would have been welcome: for example, an approach to novels that focus on trench warfare or those set in India. General readers, collectors, and researchers, however, should find this a useful compilation. - E.M.

O'Neill, Patrick. German Literature in English Translation: A Select Bibliography.
Toronto, Univ. of Toronto Pr., [1981]. 242p. \$15. LC 81-195851. ISBN 0-80202409-2.

This compilation of 1,894 entries, useful for the "teaching scholar in the humanities, the student of comparative literature, and the educated general reader" (Pref.), covers the whole range of German literature from the Middle Ages to the present. Closing date is 1979. More than half the listings are of twentieth-century writing, but good modern translations of earlier works are an important ingredient.

Unlike the earlier standard lists, B. Q. Morgan's Critical Bibliography of German Literature in English Translation and its Supplement covering through 1955 (see Guide BD615), and M. F. Smith's complementary Selected Bibliography . . . 19561960 (Guide BD617), which included many disciplines, O'Neill's compilation is limited to literature as such. And for that subject the new list virtually supersedes the older ones. Philosophy, history, anthropology, etc., are in general excluded. Nor does the compiler attempt evaluative comment as Morgan did, since his prime criterion for inclusion is literary excellence, and secondly, cultural interest.

Arrangement is in five chronological divisions: general, pre-1700, eighteenth, nineteenth, and twentieth centuries. Within each section books appear alphabetically by author. For each entry author, title, translator, place, publisher, and date are given, and the original German title is often supplied. $\mathrm{Pa}$ perback format is noted, but in-print status is not. A useful work for both graduate and undergraduate literature collections. - R.K.

\section{Performing Arts}

Balet: entsiklopediia. Gl. red. IV. N. Grigorovich. Moskva, Sovetskaia Entsiklopediia, 1981. 623p. il. 9r., 10k. LC 81482546.

Articles on dancers, choreographers, costume and set designers, composers of ballet music, ballet companies, dance terms, and individual ballets are all included in this international encyclopedia of ballet. Coverage is also extended to such areas as modern dance (e.g., there are articles on Martha Graham and Merce Cunningham), and re- 
lated dance forms such as Indian classical dance and Spanish dance, and Japanese noh theater. Despite the international scope, however, Soviet dancers who have "defected" to the West (e.g., Makarova, Nureyev) are ignored. Signed articles predominate; many have bibliographies appended.

French terms from classical ballet are entered in roman type, but non-Russian names are given in Cyrillic transliteration, with the original form of the surname in roman following the entry word. Similar treatment is accorded entries for ballets of non-Russian origin: those titles are given in Russian translation. Illustrations abound and, although small in size, reproduction of both blackand-white and color photographs is usually clear. Line drawings illustrate dance steps and positions. - E.S.

\section{ECONOMIC HistoRY}

Encyclopedia of American Economic History: Studies of the Principal Movements and Ideas. Glenn Porter, ed. New York, Scribner, [1980]. 3v. (1,286p.) \$130. LC 79-4946. ISBN 0-684-16271-7.

The general editor of this new encyclopedia points out that "despite its central place in the evolution of American civilization, economic history has never been well integrated into most historians' or most educated Americans' view of the past."-Pref. The same holds true of libraries, for in a decentralized library system, where does economic history belong?

Within broad topical sections the encyclopedia treats the "collective American economic experience as it is understood in the latter part of the 1970s." Volume I begins with a historiographical article, then moves on to an overview of the American economy in six chronological sections from "European Backgrounds" to "Economy since 1914."

The rest of the set is divided into three large sections, each reflecting the interests of a subdiscipline of history, and each showing a further topical breakdown. Thus, within "The Framework of American Economic Growth," the articles follow the approaches of economists and the "new" economic historians by surveying such topics as "Natural Resources and Energy" and "Business Cycles, Panics and Depressions." Within "The Insti- tutional Framework," appear such topics as "Slavery" and "American Business Institutions before the Railroad." Finally, under "The Social Framework," such groups as blacks and women and social forces such as the military-industrial complex and the automobile are treated.

Contributors were instructed to write for the "educated, intelligent layman," and, for the most part, each author has succeeded, writing straightforward prose and including tables and charts as well as a helpful annotated bibliography. The extensive index is a great help in moving around in such a complicated work, and there are cross-references to related articles. A list of tables would have been welcome. While the volumes are handy for definitions, they are not really quickreference tools. Rather, the reference librarian can look forward to using this encyclopedia with students and researchers as a beginning point for research and for suggesting new approaches and methodologies. E.M.

\section{Statistics}

Alderson, Michael. International Mortality Statistics. London, Macmillan; New York, Facts On File, [1981]. 524p. \$55. LC 8022536. ISBN 0-87196-514-3.

Serial mortality tables for the period 1901-75 for thirty-one countries (mainly European nations, but including Australia, Canada, Chile, Japan, New Zealand, Turkey, and the United States) are presented in this compilation. Selection of countries was based on the availability of data "in a continuous sequence throughout this century, or at least for a great part of it." - Introd. Following a series of chapters (with supporting tables and bibliographies) on the validity of mortality statistics, the effects of wars and migration on mortality statistics, published trends in the field, and the statistical methods employed, 178 "Cause of Death" tables present the data by sex, calendar period, cause of death, and country.

In addition to tables for specific causes, there are some figures for broader causes or combinations of specific causes of death, as well as tables of population estimates. There is a detailed table of contents and an alphabetical index of causes of death. The volume 
should prove useful to the person wanting comparative statistics, statistics for a given country, or information on the field of mortality statistics in general. $-E$.S.

\section{POLITICAL SCIENCE}

Arkin, William M. Research Guide to Current Military and Strategic Affairs. Washington, D.C., Institute for Policy Studies, 1981. 232p. $\$ 15.95 ; \$ 7.95$ paper. ISBN 089758-032-X.

U.S. defense posture, Soviet military doctrine, regional security, arms control and disarmament: the importance and complexity of these issues and similar ones are underscored by the overwhelming number of sources available to researchers in military and strategic affairs. Arkin, a defense and intelligence analyst, has compiled an impressive guide to the basic sources in the field, discussing more than 1,000 reference items and 600 periodicals in a series of bibliographic essays.

The opening chapter, on general information sources, is a miniguide to the entire field of international relations. The next chapter deals with U.S. government publications, describing hundreds of documents issued by congressional and executive agencies. The section on the U.S. military presents general and specialized sources on the background, organization, budget, and programs of the Defense Department and the four armed services, as well as information on national security policy, current defense posture, the military-industrial complex, and military personnel issues. A final chapter is devoted to other countries, regional security networks, and transnational military issues such as weapons systems, arms control, and international organizations.

Each chapter highlights the major English-language handbooks, bibliographies, indexes, abstracts, dictionaries, directories, yearbooks, statistical sources, translation services, and periodical literature. A recurring theme is that all researchers should exploit the raw data, the insight, and the analysis contained in U.S. government publications and current journals. The serial listings are impressive indeed: 600 titles, from the major international relations journals to the very specialized military press, are listed.
Students, researchers, journalists, activists, government workers, and librarians will all appreciate the meticulous effort that produced this outstanding guide. - L.B.

Goehlert, Robert U., and Sayre, John R. The United States Congress: A Bibliography. New York, Free Pr.; London, Collier Macmillan, [1982]. 376p. \$50. LC 81-19526. ISBN 0-02-911900-6.

Books, edited volumes, journal articles, research notes, dissertations, and theses dealing with the history, development, and legislative process of the United States Congress are included in this effort to list all the relevant "scholarly research material published in English over the last two hundred years."-Introd. General studies of national politics and government policy are not included, nor are "secondary and peripheral materials on the federal government, foreign affairs, campaigns and current events." More than 5,600 items are entered in a detailed, classified arrangement that makes for easy scanning.

A good subject index permits the user to focus on very specific topics, individual congressional elections and presidential administrations, and precise terms and areas of congressional activity. There is also an author index. While the stated emphasis on scholarly works is to be applauded, the many references to unpublished doctoral dissertations and to articles in law reviews may somewhat limit the bibliography's usefulness for "the general reader and serious students" mentioned as part of the intended audience. - E.S.

\section{History and Area Studies}

Murray, Jocelyn. Cultural Atlas of Africa. New York, Facts On File; Oxford, Phaidon, 1981. 240p. il., maps. \$29.95. LC 80-27762. ISBN 0-87196-558-5.

As the editor says in the introduction, "Whatever is said about Africa needs to be grounded in the physical realities of the continent. [This] book is first of all an atlas, but it is an atlas set within the historical context." That context, contemporary as well as historical, is provided in the accompanying text and numerous illustrations, including many beautifully reproduced (and informative) 
color photographs. Attractive as the book is, it is much more than a picture book; for within its moderate-sized $(31 \mathrm{~cm})$ format it encompasses an extremely dense but wellorganized collection of maps, articles, illustrations, and captions.

In each chapter the pictures, graphics, and text (including signed articles) work together to present facts and expert opinion about all aspects of Africa's geography, culture, and national identities. Although intended primarily to provide synthesis and overview, the work is surprisingly detailed and covers a broad range of topics relating to physical geography, languages and peoples, religion, arts, archaeology and history, education, plus a number of special topics such as "Traditional House Types" and "Game Parks and Conservation."

Approximately half of the atlas is devoted to articles and large maps for each of the regions and nations of Africa (including recent basic statistics). The thoroughness and sophistication of this endeavor is confirmed by the list of contributors, the careful identification of each illustration, the up-to-date bibliography, the gazetteer/index, and the subject/name index. All for under $\$ 30 !-A . L$.

\section{Neely, Mark E. The Abraham Lincoln Ency- clopedia. New York, McGraw-Hill,} [1982]. 356p. il. \$45. LC 81-7296. ISBN 007-046145-7.

Neely's encyclopedia is a model of what an encyclopedia should be. Audience and subject are well defined, and the articles are focused, authoritative, and well researched. Each article treats some particular aspect of Lincoln: his relations with contemporaries and family members, his conduct as commander in chief (no battles are included since Lincoln was not a field general), events in which Lincoln had the major role, elements of the man (education, physical appearance), and his ideas (e.g., attitude toward the Indians). Consideration is also given to persons associated with Lincoln, such as famous biographers, collectors, and "latterday Lincoln-haters."

Each article presents a synthesis of what is known on the topic, based on previously published research as well as on Neely's own research; each concludes with a discussion of published sources. The many illustrations - photographs, portraits, cartoons, printsseem particularly well chosen and appropriate. The index is careful and detailed, with the major article on a subject set in boldface type.

This encyclopedia is invaluable for anyone with an interest in Abraham Lincoln.E.M.

Patterson, Maureen L. P. South Asian Civilizations: A Bibliographic Synthesis. Chicago, Univ. of Chicago Pr., [1981]. 853p. maps. \$50. LC 81-52518. ISBN 0-22664910-5.

It has been more than twenty years since publication of Patterson and Inden's South Asia: An Introductory Bibliography (Chicago, 1961), a guide to selected Westernlanguage works on Indic civilization. The present work has evolved from that title, although not without a complete reorganization of the original classification scheme, which followed "Eurocentric" academic categories. In order "to do justice to the complexity and 'foreignness' of Indic civilization [and] show interrelationships and juxtapositions of ideas and events within chronological blocs," a classification scheme was developed "from the earliest to the latest; from subcontinental or pan-Indian to regional and local; from the general to the specific."Introd.

The system "gathers materials from several disciplines within a single period, sorts it by spatial [geographic] unit, and presents it in a consistent sequence-political context, economic conditions, social development, religio-philosophical traditions, and literary and artistic expression." The "Outline of Headings," a very detailed table of contents, covers eighty-three pages and is virtually an outline of Indic civilization.

Modestly describing this as a "highly selective work limited to western-language sources," the compiler provides citations to more than 28,000 generally available and recent books, essay collections, substantive periodical articles, government reports, and dissertations. Chapters are grouped in five main sections: (1) an overview of Indic civilization and the Hindu world view; (2) a chronological survey from prehistoric times to the nineteenth century; (3) a historical outline of the development of the indepen- 
dent nation states of India, Pakistan, Bangladesh, Nepal, Bhutan, Sri Lanka, and the Maldives; (4) a survey of eight geocultural areas; and (5) general reference sources, traveler's guides, teaching materials, language tools, and union catalogs. Author and subject indexes conclude the volume.

The product of a very special and individualistic scholarship, sensitivity to Indic civilization, and bibliographic skill, the work is handsomely produced, reasonably priced, and a fitting tribute to the impressive civilization it so ably introduces. -D.G.

\section{SCIENCE ANd TeChNOLOGY}

Jayawardene, S. A. Reference Books for the Historian of Science: A Handlist. London, Science Museum, 1982. 229p. (Science Museum. Library. Occasional Publication, 2) £3 paper. ISBN 0-901805-14-9.

More than a thousand entries are included in this guide for historians of science to satisfy their requirements for historical and general reference works as well as for titles in their areas of specialization. The "list does not pretend to offer the historian of science a ready answer to every problem," but "aims at providing him with a wide range of tools to help him solve them."-Introd.

Entries are presented in three sections ("History of Science and Its Sources," "History and Related Subjects," "General Reference"), which are appropriately subdivided into forty-four classes by subject, period, or form. Many types of reference works are included, e.g., guides, manuals, bibliographies, histories, dissertation lists, and periodicals. Bibliographical information is complete, and locations (in London libraries) are often noted. There is an index of authors/titles, and an index of subjects. R.K.

Myers, Darlene. Computer Science Resources: A Guide to Professional Literature. White Plains, N.Y., Publ. for American Society for Information Science by Knowledge Industry Pubns., [1981]. 346p.

LC 81-559. ISBN 0-914236-80-6.

Designed as a practical guide to important and often-needed information in the computer science field, this reference book brings together various types of information in a single well-organized combination bibliography/directory/handbook. The bulk of the volume consists of selected bibliographies of current books, journals, technical reports, reference sources, university computer center newsletters, references on computer programming languages, and proceedings of the Association for Computing Machinery Special Interest Groups. Some lists are annotated, and most provide subject access. Three of these bibliographic chapters are devoted to reference sources, including indexing and abstracting resources, directories, dictionaries, handbooks, and guides to software resources.

Address and directory information is given for academic computer centers and computer center libraries, associations, publishers, trade fairs and shows, and other industry sources. In addition, acronyms are defined, an expansion of the Library of Congress QA75 and QA76 classifications is proposed, and a concise overview of background information and resources is provided in the introduction to each chapter.

According to the preface, this book addresses "the needs of researchers, managers, librarians, consultants and systems analysts in academic, corporate and governmental data processing centers." However, because the book contains so much information so clearly presented, with such useful annotations and chapter introductions, it could also be valuable in many science, engineering, and general reference collections that serve students or others interested in "the descendants of Babbage's marvelous machine."A.L.

Rink, Evald. Technical Americana: A Checklist of Technical Publications Printed before 1831. Millwood, N.Y., Kraus International Pubns., [1981]. 776p. \$60. LC 81-4036. ISBN 0-527-75447-1.

Technology has been defined very broadly by the compiler of this checklist to garner some 6,065 published works on the various technologies and "those which indicate the advocacy and the extent of the application of technological improvements, as well as the availability of products created by such applications."-Introd. The resulting bibliography demonstrates the interests and the 
development of technology in the United States from 1683 through 1830 (selected as the cutoff date to keep the checklist in a manageable form). Users of the volume should consult the introduction to learn the inclusion policies for certain categories of general works (e.g., encyclopedias and manuals, travel books, and gazetteers are included selectively, while other categories or specific subjects, such as medicine, journal articles, or cookbooks, are excluded).

Materials are listed under topical headings within broad subject categories, then by date of publication. There is a good index. The bibliographical information is complete; notes explain the subject of a volume and clarify authorship or publication details. Locations are given for U.S. libraries. Item numbers for "Early American Imprints," the microform editions based on the Evans and Shaw and Shoemaker bibliographies, are given when available. When these numbers are not available, reference is made to a bibliographical source. This is a valuable bibliography, carefully compiled and very thorough in its coverage. - E.M.

\section{New Editions, Supplements, Etc.}

With the appearance of V.754 (published 1981), the supplement to The National Union Catalog, Pre-1956 Imprints (Suppl. 2AA9) is now complete. Frequent users of the basic set who have long been encountering see references to the supplement will be pleased to have that gap closed, just as they will welcome the additional locations found at the end of each supplementary volume. A reprint of the eleventh edition of Symbols of American Libraries (Washington, D.C., 1976) is included in V.754. Mansell Publishing and the $N U C$ staff deserve warm praise for maintaining a rigid production schedule and high-quality work over the many years of publication.

The 1911-65 series of the Gesamtverzeichnis des deutschsprachigen Schrifttums (GV) (see Suppl. AA119) is now complete in 150 volumes. The final volume (München, K. G. Saur, 1981) includes a brief "Nachträge" section, pages 399-411.

The third edition of The Video Source Book (Syosset, N.Y., National Video Clearinghouse, 1981. 1,529p. \$95; 2d ed., 1980;
Suppl. 2AA50) lists nearly 35,000 prerecorded programs available on video from some 650 sources. A separate listing of videodiscs has been added in this edition.

With successive editions promised on a triennial basis, the third edition of Kenneth F. Kister's Encyclopedia Buying Guide (New York, Bowker, 1981.530p. \$22.50) evaluates thirty-six in-print English-language encyclopedias published or distributed in the United States and Canada. A major change since the previous edition (1977; Suppl. AC1) is the grouping of entries in five size/user categories (e.g., multivolume adult encyclopedias) rather than a single alphabetical listing of titles.

Ralph DeSola's Abbreviations Dictionary has appeared in an "expanded international sixth edition" (New York, Elsevier, 1981. $966 \mathrm{p}$. \$35) with the text fully revised and reset. As in the fifth edition (1978; Suppl. AD7), acronyms, appellations, eponyms, nicknames, and a variety of other short forms, pseudonyms, geographic names, etc., are interfiled with the abbreviations. There has been a number of additions to the appended lists and tables.

Leland G. Alkire is again the editor of $\mathrm{Pe}$ riodical Title Abbreviations, the third edition of which has appeared in two volumes (Detroit, Gale, 1981. V.1, by abbreviation, $\$ 75$; V.2, by title, $\$ 85)$. The more than 35,000 abbreviations included represent an increase of about 75 percent over the second edition (1977; Suppl. AE5). An annual supplement to V.1 will be entitled New Periodical Titles and is to be designated as V. 3 of the set.

Biography and Genealogy Master Index (Detroit, Gale, 1980. 8v. \$575) forms a second edition of Biographical Dictionaries Master Index (1975; Suppl. AJ2). As indicated in the subtitle, this edition has been expanded to index some $3,200,000$ biographical sketches in more than 350 works of collective biography and related sources.

A list of additions and corrections for the first five volumes of the Dictionary of Labour Biography (London, Macmillan, 1972- ; Guide AJ167a, Suppl. AJ47, 2AJ38) is included in V.6 of the set (published 1982). That volume also concentrates "to some extent on radicals of the pre-1850 decades" in the hope that "this emphasis 
upon Chartists, Owenites and other individuals involved in the radical movements of these early decades will help to redress the balance of . . . previous coverage." $-[p . v i i]$.

With the 572 biographies included in Supplement Seven, 1961-1965 (New York, Scribner, 1981. 854p. \$55), the Dictionary of American Biography (Guide AJ41) now encompasses a total of 17,656 sketches. John A. Garraty continued as editor of this latest supplement.

J. P. Wearing's The London Stage, 1900-1909: A Calendar of Plays and Players (Metuchen, N.J., Scarecrow Pr., 1981. 2v. $\$ 50)$ offers a continuation of the compiler's earlier listings (see Suppl. BG12), the two sets now providing a day-by-day record of London stage productions for the period 1890-1909.

The second edition of the Handbuch der Museen/Handbook of Museums: Bundesrepublik Deutschland, Deutsche Demokratische Republik, Österreich, Schweiz, Liechtenstein (München, K. G. Saur, 1981 [dist. in U.S. by Gale]. 779p. $\$ 175$ ) offers directory information on 1,760 museums in the countries indicated. Adoption of a larger page size has resulted in the single-volume presentation rather than the two-volume format of the 1971 edition (Guide BE69).

Francis P. Prucha's Indian-White Relations in the United States: A Bibliography of Works Published 1975-1980 (Lincoln, Univ. of Nebraska Pr., 1982. 179p. \$14.95) forms a supplement to the same compiler's Bibliographical Guide to the History of IndianWhite Relations . . . (1977; Suppl. CC195). Classification of entries is basically the same as in the earlier volume, with a few new subheads added and a few others eliminated in view of the shorter time space covered. Any post-1974 items listed in the original volume are repeated here.

Subarctic, edited by June Helm (Washington, D.C., Smithsonian Institution, 1981. 837p. \$22), forms V.6 of the Handbook of North American Indians (Suppl. CD25, $2 \mathrm{CD} 13)$. It is the fourth volume to be published in the twenty-volume set. The culture area dealt with in this volume "encompasses approximately $2,000,000$ square miles and extends from the coast of Labrador on the Atlantic Ocean to Cook Inlet and beyond on the Pacific."-Introd. Signed contributions by some fifty scholars are included; full citations to all works referred to in the articles are brought together in the bibliography on pages 741-804.

The James Ford Bell Library: An Annotated Catalog of Original Source Materials Relating to the History of European Expansion 1400-1800 (Boston, G. K. Hall, 1981. 493p. \$95) is a main-entry listing of the University of Minnesota Library's James Ford Bell Collection as of December 31, 1980. It incorporates the listings in the previously published catalogs of the collection: Jesuit Relations and Other Americana in the Library of James Ford Bell (1950; Guide DB14) and the lists of additions thereto (Guide DB15, Suppl. DB6). The earlier catalogs remain useful for their chronological approach and for the fuller descriptions, collations, and facsimiles found in the basic volume. E.S. 